\section{Luigi Marinelli}

La Sapienza, Università

di Roma

\title{
Szymborska Zen?
}

\begin{abstract}
Szymborska Zen?

On the basis of reading Szymborska's poems, Lektury nadobowiazkowe (Non-required Reading) and some auto-thematic reflections from interviews, and referring to - among other things - the conceptions of "ordinary Buddhism" proposed by the French writer Hervé Clerc and "spontaneous enlightenment," which the Italian scholar of Chán/Zen Aldo Tollini uses in relation to the writing of Luigi Pirandello, the author suggests that the poetic world of Wisława Szymborska is deeply immersed in Zen philosophy. There are some fundamental concepts of Zen thought that shed an interesting light on the general message of this poetry, pointing out many similarities and affinities. This concerns, for example, the ironic and antiphrastic conception of poetic language, the relation between poetry and reality, as well as the method of experiencing the world based on distance and doubt.
\end{abstract}

Słowa kluczowe: Szymborska Wisława, buddyzm, Zen, polska poezja współczesna

Keywords: Szymborska Wisława, Buddhism, Zen, contemporary Polish poetry

Kto wie, poetka byłaby pewnie zdziwiona albo i rozbawiona moim pomysłem, ale właśnie pokusa, by wywołać uśmiech Wisławy w niebie przekonała mnie w końcu, by zaproponować to odczytanie poezji Szymborskiej, może trochę zaskakujące, a dla wielu zapewne wręcz „nie do pomyślenia”. Jestem jednak przekonany (tak samo jak wcześniej ona), że „co nie do pomyślenia jest do pomyślenia" (a czasami warte przemyślenia)... 
Weźmy za przykład słynny incipit „Nicość przenicowała się także i dla mnie" - pierwszy wers przyciągający uwagę szczególnie, gdyż nadaje tytuł wierszowi bez tytułu (a zatem zaczynającemu się w pustce) i jest tym bardziej znaczący, że to zjawisko w kanonie Szymborskiej niezwykle rzadkie.

Dla filozofii Chán/Zen właśnie pojęcia pustki i nieobecności są podstawą rzeczywistości, gdyż nicość, „nieistnienie” to pierwszy warunek „istnienia” (tak zwana Sutra serca, jeden z najsłynniejszych i najważniejszych tekstów buddyzmu Zen, stawia w istocie znak równości ,między zjawiskami, to znaczy tym wszystkim, co jest dostępne zmysłom, shiki, i pustką, $k \bar{u}$ ’1); a zresztą w tekstach wielkich mistrzów i patriarchów chińskich oraz japońskich kierunek tego typu rozumowania przebiega zazwyczaj po binarnych liniach (fałszywych) przeciwieństw czy pseudotautologii, wyrażonych zwykle w sposób niebezpośredni, enigmatyczny, paradoksalny, ironiczny i antyfrastyczny.

To samo, prawie to samo, a czasami dokładnie to samo zdarza się w dyskursie poetyckim (a także w krótkich formach prozatorskich) Wisławy Szymborskiej. Także w jej wizji świata wojna i trawa na łąkach, radość i smutek (Trochę o duszy), zachwyt i rozpacz (Niebo), koniec i początek, czas i wieczność, sen i jawa, konieczne (ale nigdy oczywiste) rozróżnienie między przyczynami i skutkami, przeciwstawne uczucia, ciało i dusza, niebo i ziemia, życie i śmierć - wszystko to nie unieważnia jedności Istnienia, a raczej naszego poszczególnego Istnienia Tutaj, na Chwile, która została nam dana „pod jedną z gwiazd prowincjonalnych" (Sto pociech).

Jak pisze w wierszu Niebo (inc. „Od tego trzeba było zacząć”), który nie przypadkiem otwiera zbiór Koniec i początek (1993):

Podział na ziemię i niebo

to nie jest właściwy sposób

myślenia o tej całości -

Ta „całość” zdaje się przypominać Drogę Zen do oświecenia, którą odnajdujemy, wyrażoną w podobnych słowach, w Strofach wiary w umyst, słynnym poemacie Sēngcàna, żyjącego w VI wieku n.e. drugiego patriarchy chińskiego buddyzmu Chan, założonego przez Bodhidharmę²:

Dotrzeć do Drogi nie jest trudno,

jeśli tylko przestanie się dokonywać wyborów.

Jeśli nie gardzi się i nie ulega oczarowaniom,

ten zanieczyszczony świat jawi się nam świetlisty.

Lecz gdy tylko pojawi się w nim szczelina cienka jak włos, niebo oddziela się od ziemi.

Jeśli chcesz ujrzeć prawdziwą rzeczywistość, nie patrz na rzeczy jako przychylne lub nieprzychylne.

Dać się omotać dualizmowi przychylności i nieprzychylności,

A. Tollini, Lo Zen. Storia, scuole, testi, Torino 2012, s. 29.

2 Por. ibidem, s. 32-33. 
jest chorobą umysłu.

Jeśli nie pojmujesz tego głębokiego znaczenia,

uspokajanie myśli staje się bezużytecznym trudem.

Pełnia jest niczym wielka pustka:

niczego jej nie brakuje, niczego nie jest za dużo.

„Ten zanieczyszczony świat jawi się nam świetlisty”... W tym samym duchu czternaście wieków później także Szymborska postara się nas przekonać, że „nie bez powabów jest ten straszny świat” (Rzeczywistość wymaga).

Między wydaniem zbiorów poetyckich Koniec i początek i Chwila (2002) upłynęło prawie dziesięć lat. Po drodze wydarzyła się ,tragedia sztokholmska” Literackiej Nagrody Nobla i jej „straszliwe” konsekwencje, które zaburzyły spokój prywatnego życia poetki. Porusza i budzi wzruszenie to, co piszą Bikont i Szczęsna, dwie wspaniałe biografki Szymborskiej, na temat jej absolutnej „wierności” pewnym tematom, niezależnie od (bardzo różniących się między sobą) ról, okresów i miejsc jej życia. I tak, w pierwszych Lekturach nadobowiązkowych, recenzując w 1973 roku książkę Stanisławy Wysockiej, Szymborska oświadczała, że „bardzo zastanowiło ją” jedno ze zdań, do tego stopnia, że czuła potrzebę wskazania jego dokładnej lokalizacji: „strona trzydziesta pierwsza, dziesiąty wiersz od góry”. Zdanie to, w którym dostrzegła cenną perłę ukrytą wśród różnych rozważań tej wielkiej aktorki o teatrze, brzmiało: „Dusza odpoczywa nie tylko w śmiechu, ale i w czystym smutku"3. I właśnie pierwszym wierszem opublikowanym po otrzymaniu Nagrody Nobla, ponad ćwierć wieku po napisaniu tej krótkiej recenzji, będzie Trochę o duszy:

\section{Radość i smutek}

to nie są dla niej dwa różne uczucia.

Tylko w ich połączeniu

jest przy nas obecna.

Czym jest dla niej dusza, wyjaśniła Szymborska w wywiadzie z 2002 roku, zatytułowanym Trudno jest wspinać się do wiersza, w słowach najprostszych i zrozumiałych dla wszystkich: ,Ten moment, kiedy człowiek jest otwarty na jakieś rzeczy wznioślejsze niż codzienność, to jest dla mnie dusza"4. A zatem do tych najwznioślejszych rzeczy możemy zaliczyć bez wątpienia także i to, że - jak czytamy w wierszu Koniec i początek:

musi ktoś sobie leżeć

z kłosem w zębach

i gapić się na chmury.

3 W. Szymborska, Wszystkie lektury nadobowiązkowe, Kraków 2015, s. 321. Dalej jako WLN z podaniem numeru strony.

4 W. Szymborska, Trudno jest wspinać się do wiersza, rozm. J. Szczęsna, „Gazeta Wyborcza", nr 203, 31.08.2002, s. 7. 
Nie jest to może „siedząca medytacja” ze skrzyżowanymi nogami (chińskie zuòchán, japońskie zazen), fundamentalna dla całej szkoły filozofii Chán/ Zen, jednak w pewien, iście szymborski sposób, dość blisko ją przypomina. Uzasadnione wydaje się też przypuszczenie, że nawet w swej powszechnie znanej dyskrecji i prostocie, a zwłaszcza w przyjęciu do wiadomości uniwersalnej coincidentia oppositorum, którą tak często odsłania w swoich wierszach, mimo iż nie odwołuje się nigdy do tego terminu - tak chętnie używanego i nadużywanego przez innych współczesnych poetów oraz pisarzy zachodnich - poezja Szymborskiej mimowolnie, a może i mimowiednie, jest głęboko zanurzona w filozofii Zen. Czy też, by ująć to inaczej i oględniej, jeśli popatrzymy na pewne fundamentalne koncepty myśli Zen i odniesiemy je do poezji Szymborskiej, rzucą one wiele światła na jej ogólne przesłanie. Czy można jednak nie potraktować jako owocu swoistej „postawy Zen” zdań takich jak to, pochodzące z przezabawnej „lektury nadobowiązkowej” polskiego thumaczenia bestselleru Dale'a Carnegiego How to Stop Worrying and Start Living:

Brak zmartwień byłby jeszcze gorszy niż zmartwienia. Świadczyłby o braku wyobraźni, wrażliwości i duchowym prostactwie ${ }^{5}$.

Także troska o „najrozmaitsze psychozy i nerwice” psów (właśnie ze strony tej, która znana jest powszechnie i raczej niesłusznie jako wielka miłośniczka kotów) oraz wyrażane w prozie i poezji docinki pod adresem niekonsekwencji wegetarianizmu wydają się wynikać w prostej linii z tej samej postawy. Wystarczy poczytać choćby wiersz Przymus (z pośmiertnego Wystarczy):

Zjadamy cudze życie, żeby żyć.

Denat schabowy z nieboszczką kapustą.

Karta dań to nekrolog.

[...]

Nawet poeci najbardziej liryczni,

nawet asceci najbardziej surowi

żują i przełykają coś,

co przecież sobie rosło.

Albo „lekturę nadobowiązkową” Wysoki Sądzie , w której zapowiadała te same przemyślenia, które wyraziła potem w zacytowanym przed chwilą wierszu:

Może narażę się tutaj ludziom uprawiającym ideowy wegetarianizm, ale przecież rośliny to także organizmy wyposażone $\mathrm{w}$ wolę życia. W innych formach się

5 Eadem, WLN, s. 705.

6 Eadem, WLN, s. 420.

7 Eadem, WLN, s. 673-674. 
ta wola przejawia, czy to jednak znaczy, że jej nie ma? Jakkolwiek byśmy ją określili, faktem jest, że kończy się ona definitywnie na talerzu jarosza...

Tę samą myśl rozwija wiersz Milczenie roślin, wspaniała, melancholijna refleksja nad ,jednostronną znajomością” i niemożliwością dialogu z istotami żyjącymi i często tak uroczymi i kochanymi:

Rozmowa z wami konieczna jest i niemożliwa.

Pilna w życiu pospiesznym

i odłożona na nigdy.

A także poruszające, smutno ironiczne słowa podsumowujące ,lekturę nadobowiązkową" książki Petera Teichmanna Gdy zachoruje pies ${ }^{8}$ :

Istnieje przecież sto innych sytuacji, w których pies traci równowagę, balansując bez przerwy między wymogami własnej natury i obcego mu ludzkiego świata. Wreszcie, prędzej czy później, zaczyna kręcić się za własnym ogonem, co podobno nie jest wesołą igraszką, ale sygnałem, że nasz wychowanek traci poczucie rzeczywistości. U ludzi ten etap choroby, z braku ogona, przechodzi bezobjawowo.

W sumie ,nie-filozofia” czy, jak nazwał ją ktoś inny, „filozofia praktyczna” Tutaj (2009), Chwili (2002) i Dwukropka (2005), wierszy, które dały tytuł jej ostatnim zbiorom poetyckim, jest być może wystarczającym dowodem tego, co chcemy tutaj udowodnić:

Jakby nie przesuwały się tędy niziny

w gorączkowych malignach,

lodowatych dreszczach.

Jakby tylko gdzie indziej burzyły się morza

i rozrywały brzegi horyzontów.

Jest dziewiąta trzydzieści czasu lokalnego.

Wszystko na swoim miejscu i w układnej zgodzie.

(Chwila)

Prawdę powiedziawszy, nie istnieje wiersz zatytułowany Dwukropek, ale w utworze zacytowanym wcześniej, noszącym tytuł Właściwie każdy wiersz i zamykającym tomik Dwukropek, a zarazem otwierającym go w nieskończoność tym znakiem interpunkcyjnym zamieszczonym na końcu, Szymborska prowadzi dalej dialog z samą sobą i czytelnikiem, zauważając:

Właściwie każdy wiersz

mógłby mieć tytuł „Chwila”.

(Właściwie każdy wiersz)

\footnotetext{
8 Eadem, WLN, s. 419-420.
} 
Chwila w czasie i dwukropek w przestrzeni zdania są dla Szymborskiej ekwiwalentami życia, czyli czegoś przemijającego, przejściowego i zarazem nieskończonego, nieograniczającego się do indywidualnego, pojedynczego istnienia ludzkiego. Z tego punktu widzenia wiersz Nieuwaga (znajdujący się też w zbiorze Dwukropek) wydaje się doskonałym ironiczno-antyfrastycznym wykładem buddyjskiego pojęcia (i praktyki) ,uważności”, które Miłosz wytłumaczył nam swoim liryczno-profesorskim tonem w jednej z małych próz Pieska przydrożnego, a które dla Szymborskiej stanowi podstawę „,kosmiczn[ego] savoir-vivre[,u]”, czyli „zdumionego udziału w tej grze / o regułach nieznanych", jak sama pisze na końcu tego wiersza.

W długim wywiadzie pod sugestywnym, zainspirowanym Kałuża Szymborskiej, tytułem Wchodzimy w tajemnice jak w katuzę, wybitny tłumacz, poliglota i eseista Ireneusz Kania, znawca kabały, kultur i religii Wschodu, a także polski redaktor ważnych tekstów buddyjskich, wyrażając swoją opinię o dziełach i osobowości Wisławy Szymborskiej, mówił, że jest przekonany, iż jej religijny agnostycyzm rodzi się z „,wyczuci[a] transcendencji rzeczywistości”, z jej „własne[go] doświadczeni[a] egzystencjalne[go]”, i że niektóre domniemane wątki buddyjskie w wierszach Szymborskiej „nie wynika[ją] z lektur" (choć przypominał sobie, że pewnego razu udzielił poetce długiej i szczegółowej lekcji prywatnej na ten temat), lecz z samodzielnego toku myśli, istotnie „bardzo zbieżnej z buddyjsk[a]”" . Kania wspominał też o cierpieniu przyrody, zwierząt i roślin; wielkim i przypadkowym przywileju, a zarazem brzemieniu egzystencji, zwłaszcza egzystencji istot ludzkich. Przede wszystkim jednak mówił o pojmowanej w duchu kantowskim relacji podmiot-przedmiot w poznawaniu rzeczywistości - ale także tutaj wyrażanej sposobami niezależnymi od autora Krytyki czystego rozumu - takiej jak Erkennen (poznawanie głębokie, emocjonalne i intuicyjne), które nie może się jednak wyrazić, zwłaszcza w poezji, inaczej niż przez formę kennenlernen (czyli dyskursywną). I podawał przykłady wierszy, takich jak Widziane z góry, w którym niezwykle znamienna wydaje się różnica istniejąca w języku polskim między czasownikami „umierać” a „zdychać”, używanymi w odniesieniu do śmierci człowieka i zwierzęcia:

Smutek się nie udziela.

Niebo jest błękitne.

Dla naszego spokoju, śmiercią jakby płytszą

nie umierają, ale zdychaja zwierzęta

tracąc - chcemy w to wierzyć - mniej czucia i świata,

schodząc - jak nam się zdaje - z mniej tragicznej sceny.

$W$ zatrzęsieniu poetka wraca do pomnożonego niejako w nieskończoność motywu przypadkowości i niepowtarzalności każdej żyjącej istoty:

9 I. Kania, „Wchodzimy w tajemnice jak w katużę”[w:] Zachwyt i rozpacz. Wspomnienia o Wistawie Szymborskiej, oprac. A. Papieska, Warszawa 2014, s. 149, 151, 150. 
Mogłam być sobą - ale bez zdziwienia,

a to by oznaczało,

że kimś całkiem innym.

Z kolei w Widoku z ziarnkiem piasku pojawia się rozdzierająca próba przezwyciężenia wszelkiego dystansu między podmiotem i przedmiotem poznania oraz wynikający z niej pesymizm, może nie radykalny, ale nieunikniony, zawsze obecny, a także pełen współczucia dla świata i jego przypadków:

Zwiemy je ziarnkiem piasku.

A ono siebie ani ziarnkiem, ani piasku.

$[\ldots]$

Z okna jest piękny widok na jezioro,

ale ten widok sam siebie nie widzi.

Ten kto z miłości dla mnie, a także trochę dla Szymborskiej, zasugerował mi odczytanie naszej poetki „w kluczu Zen” (to jest mój partner Michele, muzyk, nawykły do refleksji i stałego „odczuwania” w najbardziej abstrakcyjnych i asemantycznych środkach wyrazu muzyki), wysunął prowokacyjne i warte namysłu przypuszczenie, że gdybyśmy chcieli za wszelką cenę szukać jakiejś , wady” tej poezji, znaleźlibyśmy ją być może w tym, iż „nie ma ona wad". Przypuszczenie to przywodzi na myśl jedną z najwcześniejszych ocen dojrzałej poezji Szymborskiej, która wyszła spod szorstkiego i wymagającego pióra Artura Sandauera. Krytyk zdefiniował ją w istocie już w 1957 roku jako „doskonałą”, bo „między dwoma skrzydłami polskiej literatury poezja ta potrafiła znaleźć słuszną miarę. Nie jest ani tradycjonalnie moralistyczna, ani awangardowo-artystowska"10. Nie wiem jednak, czy podzielam do końca tę opinię o perfekcji (a zatem o perfekcjonizmie?) poezji Szymborskiej, być może bowiem istnieje tradycja poetów - do której Szymborska z pewnością się zalicza - posiadających tę samą gorzką świadomość doskonałości (Safona? Katullus? Kochanowski? Sandro Penna?), wynikającą z wiedzy, że poezja jest wszędzie (trochę tak jak boskość w niektórych odmianach kosmicznego panteizmu), także kiedy jej nie ma. Wersy Do własnego wiersza - jednego z ostatnich utworów, napisanych przez poetkę na krótko przed chorobą i śmiercią - to właśnie mówią, w swoistym kōan Zen, tak jak w podobnych krótkich i niemal aksjomatycznych jej tekstach (w tomie Wystarczy):

W najlepszym razie

będziesz, mój wierszu, uważnie czytany,

komentowany i zapamiętany.

W gorszym przypadku

tylko przeczytany.

10 A. Sandauer, Pogodzona z historia [w:] Radość czytania Szymborskiej. Wybór tekstów krytycznych, red. S. Balbus, D. Wojda, Kraków 1996, s. 76. 
Trzecia możliwość -

wprawdzie napisany,

ale po chwili wrzucony do kosza.

Masz jeszcze czwarte wyjście do wykorzystania znikniesz nienapisany,

z zadowoleniem mrucząc coś do siebie.

Przy innej okazji w swojej Poczcie literackiej Szymborska napisała, że „poezja zaczyna się poza oczywistością" ${ }^{11}$. Można by odwrócić elementy tego zdania, można by jednak także pomyśleć, iż zarówno oczywistość, jak i poezja są częścią naszego życia i że nie trzeba być poetą, by to wiedzieć. W jednym z wywiadów Szymborska wyjaśniała bardziej szczegółowo tę myśl:

Tworzenie polega na tym, że się wyszarpuje jakąś cząstkę rzeczywistości. [...] Czasem wydaje mi się po prostu, że owa „radość pisania” polega na znalezieniu, a nawet samym poszukiwaniu tego słowa, które jest mi właśnie potrzebne, a którego niekiedy w ogóle nie ma i trzeba je stworzyć, lub na poszukiwaniu jakiejś figury stylistycznej. [...] Problem tylko w tym, że trzeba $\mathrm{z}$ niego wyciągnąć jakiś temat i przedstawić go jako problem. Poszczególna rzecz rzucona na stertę innych niewiele znaczy, ujrzana oddzielnie wygląda zupełnie inaczej. Nagle okazuje się, że natura tej jednej nawet rzeczy jest dziwnie skomplikowana. Poezja musi przekroczyć oczywistość, musi dawać jej inny wymiar ${ }^{12}$.

Zatem poezja i oczywistość rzeczywistości, nawet w jej najbardziej banalnej codzienności, są dla Szymborskiej dwiema stronami tego samego medalu albo też - by kontynuować odwołania do filozofii orientalnych - yin i yang stworzenia i życia. Z różnorodności i wielorakości tego życia oraz oczywiście przerażenia, jakie budzi, jakiekolwiek by było, a także ze zdumienia, jakie z niego wynika, Szymborska uczyniła z czasem swoje podstawowe credo poetyckie i niejako swój znak firmowy. Wszystko to jest niezwykle bliskie konceptowi shohō jissō, czyli zasadzie „każde zjawisko jest prawdziwą rzeczywistością", fundamentalnej w doktrynie Dōgena, twórcy japońskiej szkoły Zen Sōtō, według której

[...] poszukiwanie oznacza odsłonięcie niezwykłej wartości normalnego języka: tego, co każdego dnia widzą nasze oczy i słyszą nasze uszy. Jeśli podejmiemy trud, aby zrozumieć to do głębi, pojmiemy, że pełne jest głębokich znaczeń. I znowu, shohō jissō, każda pojedyczna rzecz, nawet najbardziej niepozorna, jest autentycznym wyrazem całej oświeconej rzeczywistości ${ }^{13}$.

11 Cyt. za: A. Bikont, J. Szczęsna, Pamiątkowe rupiecie. Biografia Wisławy Szymborskiej, Kraków 2012, s. 126.

12 K. Nastulanka, Powrót do źródet. Rozmowa z Wisława Szymborska [w:] eadem, Sami o sobie. Rozmowy z pisarzami i uczonymi, Warszawa 1975, s. 305-306.

13 A. Tollini, op.cit., s. 89. 
Kiedy zagłębiamy się zatem w to, co można by nazwać „postawą Zen” w wizji świata Wisławy Szymborskiej, natykamy się na dziwne zbieżności, które nie oznaczają wcale zależności, lecz pokrewieństwo, podobieństwo, zwykłe współistnienie. Zaczynając od paradoksalnego niekiedy użycia języka, który nigdy nie jest bezpośredni, a często „negatywny”, „,ironiczny”, „antyfrastyczny”, niedający odpowiedzi, za to mnożący pytania, popychający czytelnika, by sam szukał odpowiedzi i uczynił je własnymi. To strategia poetycka, która przypomina metodę pedagogiczną chińskich i japońskich mistrzów Chán/Zen, oraz szczególny język kōan, często

[...] złożony z paradoksów, zagadek i nonsensu [...] uczeń [w naszym przypadku czytelnik - przyp. L.M.] pod wpływem tego bodźca zacznie własne poszukiwanie umykającego mu quid. Słowa (albo gesty) mistrza będą podnietami, nie zaś rozwiązaniami ani odpowiedziami [...] tylko użycie języka wykraczające poza utarte konwencje [...] może pozwolić na niezapośredniczoną wizję rzeczywistości, czy przynajmniej dać jej przebłysk ${ }^{14}$.

Chodzi w sumie o owe klasyczne czy sokratejskie nescio („Wiem, że nic nie wiem"), które można wskazać jako centralny topos poetyki Szymborskiej, wyrażony wprost $\mathrm{w}$ pochwale tych dwóch małych skrzydlatych słów „nie wiem", zawartej w sławnej przemowie z okazji otrzymania Nagrody Nobla, Poeta $i$ świat. Jak pisze Daisetz Teitaro Suzuki, strategia „niewiedzy” jest zresztą typowa, a nawet podstawowa także dla „praktycznego" nauczania mistrzów oraz patriarchów Zen, i wspomina m.in. słynną odpowiedź Bodhidharmy na pytanie, kim jest - po prostu „,nie wiem"15.

W tym wszystkim przynajmniej dwa motywy zdają się tworzyć silną więź między poezją Szymborskiej i pewnymi aspektami Drogi oświecenia oraz uwolnienia od złudzeń nauczanej przez filozofię Chán/Zen. U Szymborskiej nie znajdziemy z pewnością - chyba tylko w formie żartobliwej lub sceptycznej - najmniejszej aluzji do doświadczenia wù/satori, owego „zrozumienia” czy „oświecenia” „,naszej prawdziwej natury, to znaczy tego, czym jesteśmy w rzeczywistości według wizji buddyzmu, i co w ostatecznym rozrachunku jest tożsame z wizją nie-substancjalności ja" ${ }^{16}$. A jednak przewodnie motywy poetyki Szymborskiej to właśnie nie-substancjalność i nietrwałość ja w klasycznym buddyzmie znana jako anatta (anatman), której poruszającym wyrazem zdaje się wiersz Kilkunastoletnia, oraz możliwe uśpienie i przezwyciężenie doświadczenia bólu (dukkha) przez zrozumienie nietrwałości (w doktrynie buddyjskiej znanej jako anicca) i nieskończonej wielości egzystencji, a raczej wielu egzystencji zanurzonych w Rzece Heraklita oraz w tym, co swoimi słowami Szymborska nazywała ,jarmarkiem cudów” życia.

14 Ibidem, s. 22.

15 Por. D.T. Suzuki, An Introduction to Zen Buddhism, London 1934, korzystam z wydania włoskiego: Introduzione al Buddismo Zen, prefaz. C.G. Jung, Roma 1970, s. 77.

16 A. Tollini, op.cit., s. 9. 
Anicca, dukkha $i$ anattā to trzy filary myśli buddyjskiej, które przyjmowały różne imiona i były przyswajane w różnym stopniu przez późniejszą filozofię Chán/Zen. Nietrudno znaleźć inne podobieństwa, przypadkowe wprawdzie, ale niemal dosłowne, między niektórymi wersami naszej poetki i nauczaniem dawnych mistrzów Zen, na przykład słynnym Usuhiki uta („Wiersz recytowany, gdy używa się moździerza”) Bankei Yōtaku (1622-93): „Nie istnieją rzeczy takie jak cuda i dziwy. Lecz jeśli nie rozumiesz, to wszystko, co jest w świecie, jest dziwne"17. A u Szymborskiej:

Cud pospolity,

to, że dzieje się wiele cudów pospolitych.

$[\ldots]$

Cud, tylko się rozejrzeć:

wszechobecny świat.

Cud dodatkowy, jak dodatkowe jest wszystko:

co nie do pomyślenia

jest do pomyślenia.

Podobieństwa te widać też w odniesieniu do względności każdego istnienia i piękna, które w każdej cząstce życia i rzeczywistości wynikają ze współobecności wielu różnych i nieskończonych prawdopodobieństw, jak powiadał przed ośmioma wiekami cytowany już Dōgen:

Aby badać cechy charakterystyczne rzeczywistości, widzieć nie tylko rzeczy okrągłe i kwadratowe, trzeba zważyć na wszelkie prawdopodobieństwa form mórz i gór, których jest wiele, i trzeba wiedzieć, że istnieje świat, rozciągający się we wszystkich kierunkach. I nie jest tak tylko w otaczającym nas świecie, ale także we wszystkim, co nas dotyczy i każdej pojedynczej kropli ${ }^{18}$.

Przyszła noblistka, w słynnym wierszu Nic $d w a$ razy, który stanowi jej pierwszą konfutację Eklezjastesa, a jednocześnie być może także rodzaj poetyckiej debaty ze współczesnym mu wierszem Herberta ze Struny światła, zatytułowanym Dwie krople, pisze:

Jesteś - a więc musisz minąć.

Miniesz - a więc to jest piękne.

Uśmiechnięci, współobjęci, spróbujemy szukać zgody, choć różnimy się od siebie jak dwie krople czystej wody.

(Nic dwa razy)

W związku z tym wierszem przyszła mi na myśl mała anegdota o czasie i jego niepowtarzalności, którą można przeczytać w trzydziestej drugiej ze 101 Zen stories, czyli 101 opowieści Zen, znanych również pod (iście szym-

17 Cyt. ibidem, s. 484.

18 Dōgen zenji zenshū, red. Suzuki Kakuzen i in., Tokyo 1991, s. 5. 
borskim!) tytułem Zbiór piasku i kamieni, zebranych i przetłumaczonych na angielski przez Nyogena Senzaki i Paula Repsa ${ }^{19}$ :

A lord asked Takuan, a Zen teacher, to suggest how he might pass the time. He felt his days very long attending his office and sitting stiffly to receive the homage of others.

Takuan wrote eight Chinese characters and gave them to the man:

Not twice this day

Inch time foot gem.

This day will not come again.

Each minute is worth a priceless gem.

A w polskiej wersji:

Pewien możnowładca poprosił Takuana, nauczyciela Zen, by podsunął mu pomysł na spędzanie wolnego czasu. Miał bowiem wrażenie, że jego dni dłużą się niemiłosiernie. Codziennie chodził do biura, gdzie siedział sztywno wyprostowany i przyjmował składane hołdy.

Takuan napisał na kartce osiem chińskich symboli i dał je lordowi:

Żaden dzień nie jest podwójny

Cal czas stopa klejnot.

Ten dzień nie powtórzy się.

Każda minuta jest warta tyle, co drogocenny klejnot ${ }^{20}$.

Wisława Szymborska z pewnością uśmiechnęłaby się, zdziwiona i rozbawiona moimi dywagacjami na temat tych domniemanych powinowactw. Można wskazać także inne, dużo bardziej umotywowane, na przykład: z filozofią presokratejską (w której znajdziemy wiele osobliwych podobieństw właśnie z Chán/Zen), z myślą eseistów francuskich, przede wszystkim jej ukochanego Montaigne'a, z Proustem i Heideggerem, a także z ideą „filozofii jako zdziwienia" Jeanne Hersch... Zresztą, ileż jeszcze będzie analogii i zbieżności już odkrytych lub dopiero na odkrycie czekających między filozofią „zachodnią” i „wschodnią”, w jednym wielkim „worku” ludzkiej myśli, jedynym, który się naprawdę liczy?

Skądinąd sama Szymborska wyraziła dobroduszną podejrzliwość wobec pewnych zmanierowanych form „orientalizmu”, zwłaszcza „cielesnych zasupłan”" ${ }^{21}$ Hatha Yogi, w przezabawnej „lekturze nadobowiązkowej”, poświęconej książce Hatha Joga dla wszystkich Haliny Michalskiej, gdzie wyraźnie przyjmuje postawę sceptyka, który w pewnej chwili:

19 Tuttle, Tokyo 1957, także on-line w: http://www.101zenstories.org/inch-time-footgem/ [dostęp: 10.03.2017].

${ }_{20} 101$ opowieści zen [w:] Zen z krwi i kości, przeł. R. Bartold, Poznań 1999. Także on-line w: http://przewodnikduchowy.pl/101-opowiesci-zen/koan-zen-32.php [dostęp: 10.03.2017].

${ }^{21}$ W. Szymborska, WLN, s. 382. 
[...] uprzytomni sobie, że Hatha Joga to jedynie pierwszy kroczek na drodze ku doskonałości, a ową doskonałość - w pojęciu hinduskich mędrców - osiągnie tylko ten, kto zatraci swoje indywidualne Ja we Wszechświecie. Tu sceptyk postawi sobie pytanie, czy akurat na tym powinno mu najbardziej zależeć. Może przeciwnie: zatracić się nie powinien, ale przeżyć życie do końca w swojej ludzkiej odrębności ze wszystkimi jej trudnymi konsekwencjami? Co do zatraty - zawsze będzie na nią czas po śmierci. W tym momencie sceptyk postanowi rozplątać się z Kukkutasany. Ufajmy, że zdoła bez pomocy pogotowia ratunkowego ${ }^{22}$.

A jednak, paradoksalnie, z tych zacytowanych zdań, z ich lekkiej i głębokiej ironii, ze zwykłego dla poetki pytająco-wątpiącego biegu myśli przebija mądrość bardzo bliska duchowi Zen. Jestem wręcz przekonany, że znaczną część dojrzałej poezji Wisławy Szymborskiej można by określić mianem „spontanicznego oświecenia” czy też „,bezwiednego oświecenia”, jakie Aldo Tollini $^{23}$ przypisuje końcowemu fragmentowi sztuki Pirandella Jeden, nikt i sto tysięcy (tytuł i tekst sztuki także wydają się mieć wiele wspólnego z poetyką Szymborskiej):

Powietrze jest nowe. I wszystko, chwila po chwili, jest takie, jakie jest, ożywia się, żeby się pojawić. [...] Myśleć o śmierci, modlić się. Są jeszcze tacy, którzy czują taką potrzebę, i ich głosem stają się dzwony. Ja już jej nie czuję, ponieważ umieram co chwila i odradzam się nowy i bez wspomnień: żywy i cały, już nie w sobie samym, lecz w każdej rzeczy na zewnątrz ${ }^{24}$.

Wisława Szymborska, tak samo jak Luigi Pirandello, podejmuje zatem próbę (wydaje się, że bardzo udaną) ujrzenia „rzeczy, jakimi są” (nie takimi, jakimi chcielibyśmy, aby były, albo jakimi powinny być, lecz ,jakimi one są”), by wyrazić to tytułem pięknej książeczki o „buddyzmie powszechnym”, napisanej przez francuskiego dziennikarza Hervé Clerca ${ }^{25}$.

Również wielki podziw dla obrazka japońskiego artysty Hiroshige Utagawy, wyrażony przez poetkę w słynnym wierszu-ekfrazie Ludzie na moście, zdaje się znaczącym wyrazem nigdy nie zadeklarowanej, ale oczywistej „postawy Zen” w poezji Szymborskiej. Kontrast między niepowstrzymanym upływem życia a czasem zastygłym na obrazie to wszak nic innego jak wyraz wrodzonego dualizmu duszy ludzkiej, od którego nikt nie może się uwolnić:

Ulegają czasowi, ale nie chcą go uznać.

(Ludzie na moście)

22 Ibidem.

23 A. Tollini, op.cit., s. 297.

24 L. Pirandello, Jeden, nikt $i$ sto tysięcy, przeł. J. Ugniewska, Warszawa 2011, s. $222-223$.

25 Por. H. Clerc, Le choses comme elles sont. Une initiation au bouddhisme ordinaire, Paris 2011. 
W sumie zatem „zemsta ręki śmiertelnej”, która wyraża się przez „,[c]zas, który wiążę łańcuchami znaków" (Radość pisania), rodzi się dla Szymborskiej ze świadomości i z bolesnej, lecz pogodnej akceptacji nierozwiązanej więzi między zakończeniem wiersza i (odnawianym) początkiem życia po jego zapisie/lekturze. Radość pisania (i czytania) poezji Szymborskiej wynika więc z owego ulotnego, ale aż nazbyt potrzebnego zapomnienia/oświecenia/ zrozumienia „świętości nicości” - nirwany, którą w jednym ze swych listów Pasolini łączył z ,poezją przeżytą" Sandra Penny ${ }^{26}$, oraz ze świadomości, że „tu nie jest życie” (Radość pisania). Dokładnie tak samo, jak w równie ulotnym i chwilowym (ale co nim nie jest?), radosnym i smutnym, nagim i niewinnym doświadczeniu wù/satori - stanie uwolnienia/oświecenia buddyzmu Zen - którym jest

[...] leżeć

z kłosem w zębach

i gapić się na chmury

(Koniec i poczatek)

i które „po każdej wojnie” może uratować człowieka i jego człowieczeństwo pomiędzy każdym końcem i każdym początkiem, stanowiącym wszak - jak wiemy - „tylko ciąg dalszy” (Miłość od pierwszego wejrzenia).

Także w słynnych ostatnich wersach „programowego" wiersza Koniec i poczatek słyszymy dalekie echo jakiejś „wschodniej” mądrości, bo spontanicznie przychodzą na myśl słowa wielkiego poety perskiego, założyciela bractwa wirujących derwiszy - Dżalaluddina Rumiego, współczesnego Dōgenowi i innym wielkim mistrzom Zen:

Poza ideami dobra i zła

jest tąka. Tam się spotkamy.

Kiedy dusza pokłada się w trawie

świat jest zbyt pełny by mówić.

Idee, język, nawet złączenie tych fraz

nie mają żadnego sensu ${ }^{27}$.

Czyżby prócz bycia Zen Szymborska była też trochę sufi?

26 P.P. Pasolini, List do Sandra Penny (Rzym, luty 1970 r.), opublikowany w II wydaniu Tutte le poesie S. Penny (Milano 1970). Także on-line w: https://annamariaortese.wordpress. com/2009/11/06/1342/ [dostęp: 10.03.2017].

27 Cytuję z polskiego przekładu Michała Fostowicza on-line w: http://www.pg.gda. pl/ knf/xxx2.htm [dostęp: 10.03.2017]. 


\section{Bibliografia}

Clerc H., Le choses comme elles sont. Une initiation au bouddhisme ordinaire, Paris 2011.

Dōgen zenji zenshū, red. Suzuki Kakuzen i in., Tokyo 1991.

Kania I., „Wchodzimy w tajemnice jak w kałużę” [w:] Zachwyt i rozpacz. Wspomnienia o Wistawie Szymborskiej, oprac. A. Papieska, Warszawa 2014.

Nastulanka K., Powrót do źródet. Rozmowa z Wistawa Szymborska [w:] eadem, Sami o sobie. Rozmowy z pisarzami i uczonymi, Warszawa 1975.

Penna S., Tutte le poesie, Milano 1970.

Pirandello L., Jeden, nikt i sto tysięcy, przeł. J. Ugniewska, Warszawa 2011.

Sandauer A., Pogodzona z historia [w:] Radość czytania Szymborskiej. Wybór tekstów krytycznych, red. S. Balbus, D. Wojda, Kraków 1996.

Suzuki D.T., An Introduction to Zen Buddhism, London 1934.

Suzuki D.T., Introduzione al Buddismo Zen, prefaz. C.G. Jung, Roma 1970.

Szymborska W., Poczta literacka, Kraków 2000.

Szymborska W., Trudno jest wspinać się do wiersza, rozm. J. Szczęsna, „Gazeta Wyborcza", nr 203, 31.08.2002.

Szymborska W., Wszystkie lektury nadobowiązkowe, Kraków 2015.

Tollini A., Lo Zen. Storia, scuole, testi, Torino 2012.

Tuttle, Tokyo 1957, także on-line w: http://www.101zenstories.org/inch-time-foot-gem/ [dostęp: 10.03.2017].

101 opowieści zen [w:] Zen z krwi i kości, przeł. R. Bartold, Poznań 1999. 